\title{
Observed linear trend in few surface weather elements over the Northwest Himalayas (NWH) during winter season
}

\author{
Dan Singh*, Vikas Sharma and Vikas Juyal \\ Research and Development Centre, Snow and Avalanche Study Establishment, \\ Sector 37 A, Chandigarh 160 036, India. \\ ${ }^{*}$ Corresponding author.e-mail: dan_@rediffmail.com
}

Linear trends in few surface weather variables such as air temperatures (maximum temperature, minimum temperature), snow and rainy days, snowfall and rainfall amounts, rainfall contribution to seasonal total precipitation amount, seasonal snow cover depth and snow cover days (duration) are examined from winter-time observations at 11 stations located over the Northwest Himalayas (NWH). This study indicates that snowfall tends to show a decline in this region, while the rainfall tends to increase during the winter months. Seasonal snow cover depth and seasonal snow cover days also tend to show a decline over the NWH. Decrease in seasonal snow cover depth and duration have reduced the winter period in terms of availability of seasonal snow cover over the NWH during the last 2-3 decades. Other surface weather variables also exhibited significant temporal changes in recent decades. Observed trends in temperature and precipitation over the NWH in recent decades are also supported by long data series of temperature over the western Himalayas (WH), north mountain India (NMI) rainfall data and reanalysis products.

\section{Introduction}

Large climate variability is generally observed over the mountainous regions of larger extent such as the Himalayas, the Alps, the Andes and the Rockies, etc. (Beniston et al. 1997). High mountainous regions are the integral part of the worlds' major river systems and such areas are essential elements of the global hydrological cycle. In the context of Indian subcontinent, the Himalayas play a critical role in the hydro-meteorological aspects of the major river basins in South Asia (Fowler and Archer 2005; Singh and Arora 2007), i.e., the Himalayas strongly influence the Asian Summer Monsoon circulation and associated variability. Seasonal snow cover and glaciers in the Himalayas are also important sources of fresh water.
A comprehensive understanding of the observed trends in various surface weather variables, viz., temperatures (maximum temperature, minimum temperature), precipitation, seasonal snow cover depth, etc., is quite necessary and of prime concern from the perspective of changing climate. Only a few recent studies have addressed the observed trends in temperatures, seasonal total snowfall amount and seasonal total snow water equivalent on a regional scale over the Northwest Himalayas (NWH) (Bhutiyani et al. 2007, 2009; Shekhar et al. 2010; Dimri and Das 2011) as well as the retreat of Himalayan glaciers (Kulkarni and Bahuguna 2002; Kulkarni and Alex 2003; Kulkarni et al. 2005, 2007). Consistent with increasing surface air temperatures in the NWH (Pant and Borgaonkar 1984; Li and Tang 1986; Seko and Takahashi 1991; Shrestha et al. 1999;

Keywords. Temperature; precipitation; snow cover depth; snow cover duration. 
Thompson et al. 2000; Kang et al. 2010), the aforementioned studies indicated that maximum and minimum temperatures, and the diurnal temperature ranges also indicate increasing trend during recent decades (Bhutiyani et al. 2007, 2009) which is also equally valid for other large mountainous ranges (Beniston et al. 1997; Diaz and Bradley 1997; Beniston 2003). However, seasonal totals of snowfall amount and snow water equivalent apparently indicate a severe inconsistency with other variables in the NWH region (Bhutiyani et al. 2009; Dimri and Das 2011).

One can anticipate that the decreasing trend in seasonal total snowfall amount may have resulted from the decreasing snowfall amount of shorttime intervals, snow days, and increasing rainfall amount and rain days due to increasing air temperatures over the NWH. Increasing air temperatures and decreasing seasonal total snowfall amount may have also influenced seasonal snow cover depth and seasonal snow cover days (duration) during winter season (November-April).

In this view point, a detailed analysis of observed trends of the variables listed in table 1 is undertaken in this study. The contrast between precipitation and rainfall is defined as follows. Seasonal total rainfall amount (TR) is defined as cumulative rainfall amount during the entire winter season (November-April). Seasonal total precipitation amount (TP) is defined as a sum of seasonal total snow water equivalent (water equivalent of seasonal total snowfall amount) and seasonal total rainfall amount (TR). The extension 9-15 represents time intervals of 9 or $15 \mathrm{hrs}$.

Earlier studies have examined linear trends in air temperatures, seasonal total snowfall amount and seasonal total snow water equivalent using in situ observations over the NWH (Bhutiyani et al. 2007, 2009; Shekhar et al. 2010; Dimri and Das 2011). In this study, linear trends in basic surface weather variables such as maximum temperature, minimum temperature and seasonal total snowfall amount, etc., and many other derived variables like snow days, rain days, seasonal total rainfall amount and snow cover depth, etc., are examined to provide a broad overview of trends in surface weather variables over the NWH in recent decades. Surface weather variables taken for this study are listed in table 1. Trends in temperatures (MX, MN and MNT) and precipitation over the western Himalayas (WH) are also examined using regional (sub-divisional) scale temperature data over the WH and north mountainous India (NMI) rainfall data downloaded from the website of the Indian Institute of Tropical Meteorology, Pune (IITM, Pune) (http:// www.tropmet.res.in)(Pant and Rupa Kumar 1997; Kothawale and Rupa Kumar 2005; Sontakke et al. 2008) and reanalysis products provided by National Centres for Environmental Prediction (NCAR/ NCEP) (Kalnay et al. 1996).

Observed linear trends in temperatures and precipitation at three station locations, viz., D (2192 $\mathrm{m}), \mathrm{E}(3050 \mathrm{~m})$ and I $(3800 \mathrm{~m})$, over the NWH are also compared with the regional scale trends in temperatures and precipitable water content (PWT) over the WH and the NMI rainfall. Agreement between regional scale trends in temperature, PWT and NMI rainfall with the observed trends in temperature and precipitation over the NWH in recent decades indicate that regional scale data may provide an insight on long term trends in temperature and precipitation over the NWH. Similarity of observed trends in each variable at 11 stations located widespread over the NWH is examined as the percentage (number) of stations showing same type of trend. This can be taken as an indicator of overall observed trend in each variable over the NWH in recent decades.

\section{Study area and data}

The study area falls in the Shamshabari Range, the Pir Panjal Range and the Great Himalayan Range

Table 1. List of surface weather variables and their abbreviations.

\begin{tabular}{|c|c|c|}
\hline Sl. no. & Variable & Abbreviation \\
\hline 1 & Maximum (minimum) temperature & MX(MN) \\
\hline 2 & Mean temperature & MNT \\
\hline 2 & Seasonal total snow (rain) days & $\mathrm{SFD}(\mathrm{RFD})$ \\
\hline 3 & Seasonal total precipitation days & $\mathrm{TPD}$ \\
\hline 4 & Snowfall (rainfall) amount for 9 or 15 -hr interval & SF9-15(RF9-15) \\
\hline 5 & Snowfall amount for 24-hr interval & $\mathrm{SF}-24$ \\
\hline 6 & Seasonal total snowfall (rainfall) amount & $\mathrm{TS}(\mathrm{TR})$ \\
\hline 7 & Seasonal total precipitation amount & $\mathrm{TP}$ \\
\hline 8 & Rainfall contribution to seasonal total precipitation amount & $\mathrm{RC}$ \\
\hline 9 & Seasonal snow cover depth (snow cover days) & MSSCD(SCD) \\
\hline 10 & Seasonal total precipitable water content & PWT \\
\hline
\end{tabular}




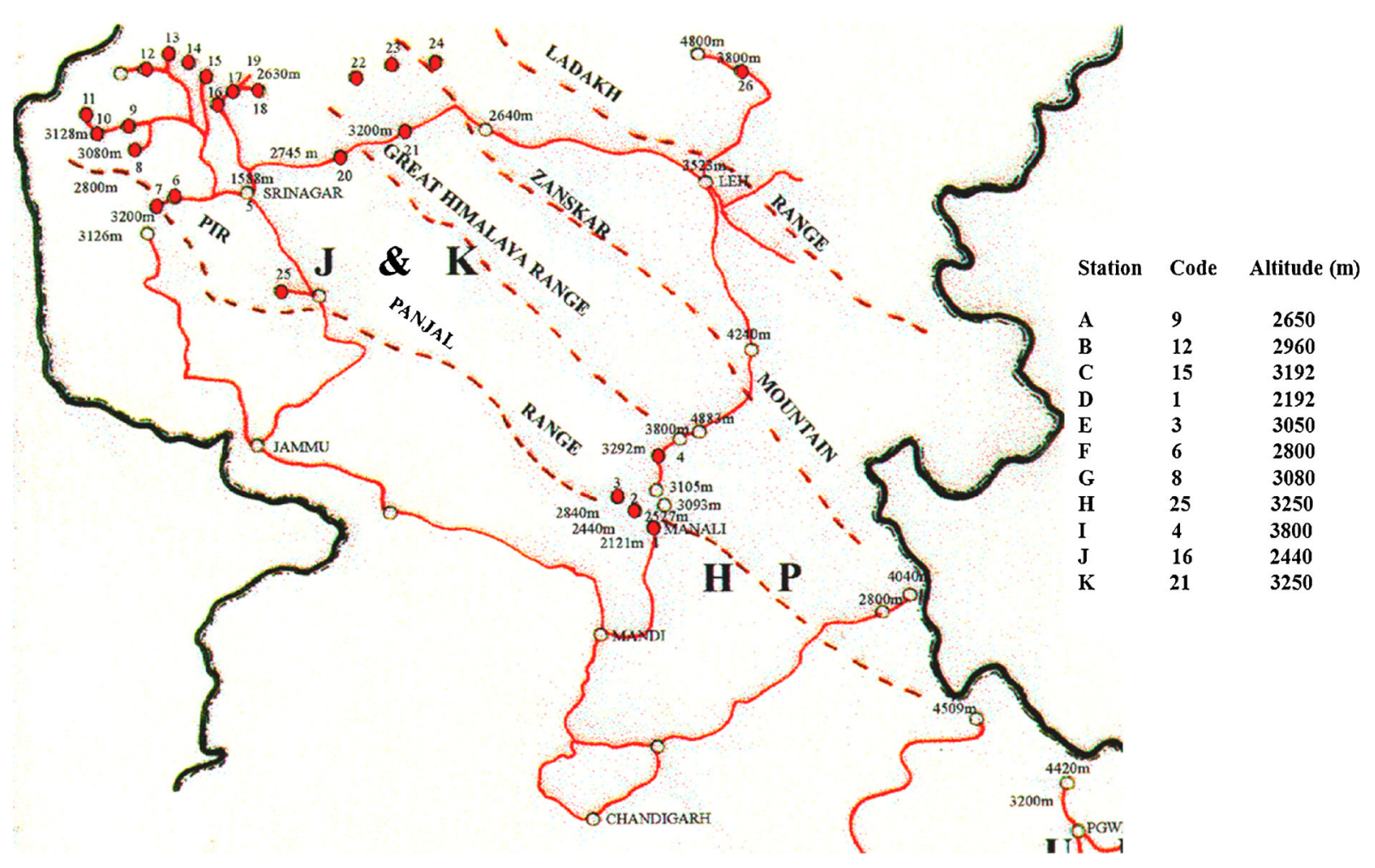

Figure 1. Study stations in different mountain ranges over the Northwest Himalayas (NWH).

in the NWH in India (see figure 1), which covers the high altitude mountainous regions of the north Indian states of Himachal Pradesh (HP) and Jammu and Kashmir (J\&K). Winter-time data (November-April) from 11 stations in different mountain ranges spread across the NWH are used for analysis of linear trends in variables listed in table 1. Data for this study is obtained from the data archive of Snow and Avalanche Study Establishment (SASE), Manali, India (Bhutiyani et al. 2007, 2009; Shekhar et al. 2010). Due to prevailing sub-zero temperatures and solid precipitation in the form of snow at most of the stations during November-April, this period is considered as a winter season over the NWH.

Daily surface weather data over the NWH are collected at 0300 and 1200 UTC, and the details can be seen in Bhutiyani et al. (2009) and Dimri and Das (2011). Data collected on snowfall (rainfall) amount at 0300 UTC represents 15-hr interval [i.e., 1200 UTC (previous day)-0300 UTC (current day)] cumulative snowfall (rainfall) amount. Data collected on snowfall (rainfall) amount at 1200 UTC represents 9-hr interval (0300-1200 UTC of same day) cumulative snowfall (rainfall) amount. FS-24 considers snowfall amount over a period of 24 hours. New snow density of $100 \mathrm{~kg} \mathrm{~m}^{-3}$ is assumed to compute snow water equivalent, if new snow density is missing or could not be recorded, and $\mathrm{RC}$ is computed as percentage of proportion of seasonal total rainfall amount in seasonal total precipitation amount. Snowfall and rainfall amounts are reported as zero on days when snowfall and rainfall do not occur.

A winter with missing data length for less than 5 days only is considered for the study. Only those stations are considered where the data reliability is high (Bhutiyani et al. 2007, 2009; Shekhar et al. 2010; Dimri and Das 2011) and spurious values in any parameter are excluded from the analysis. It is generally seen that more than $95 \%$ of the records of various variables fall within the range of mean \pm 3 standard deviation. Winter data for stations $\mathrm{D}$ and $\mathrm{E}$ are available continuously for successive winters and the data length at stations D, E and I is comparatively more than the other stations (table 2).

The climatology of MX, MN, TS, TP, SFD and RFD (see also the explanations for the variables described in table 1) at 11 stations is given in table 2. Large difference in TS (TP) at 11 stations indicates that precipitation displays a large interannual variability and strong regional character over the NWH.

\section{Methodology}

The standardized anomalies of MX, MN, TS,TR, TP, RC, FS 9-15, RF 9-15, FS-24 and MSSCD at a station for a winter are computed as follows (Pant and Rupa Kumar 1997; Bhutiyani et al. 2007):

$$
S_{j}=\frac{x_{j}}{s t_{j}}
$$




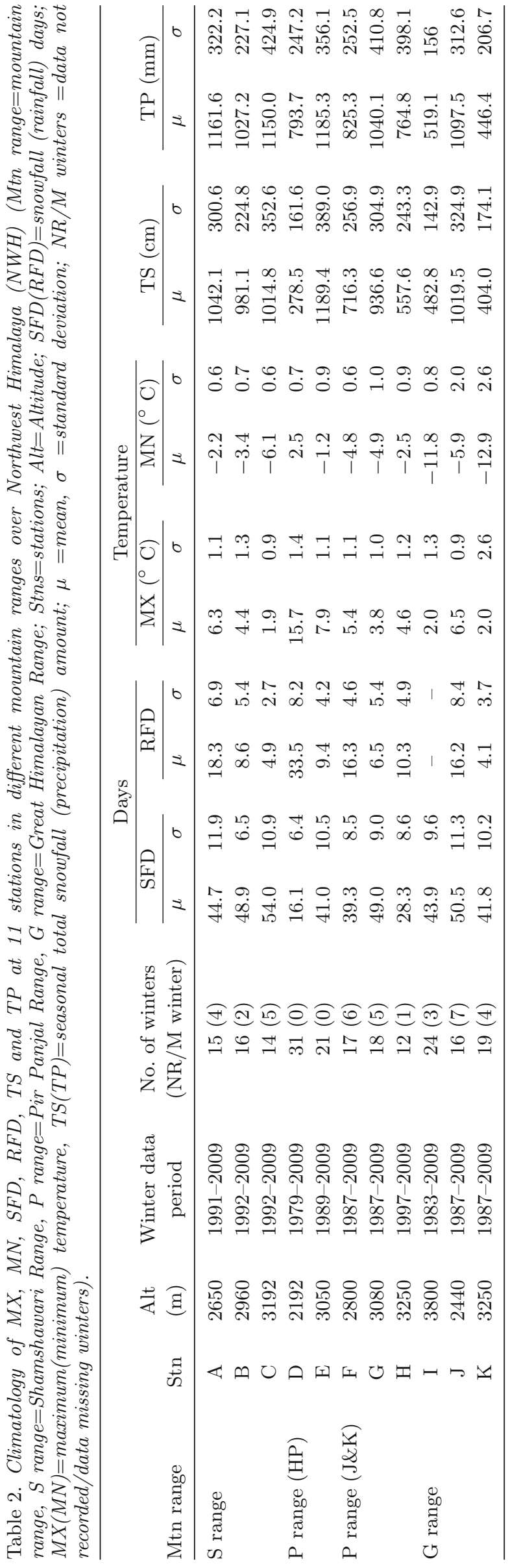

where $S_{j}=$ standardized anomaly of variable listed in table $1 ; x_{j}=$ anomaly from mean; and $s t_{j}=$ standard deviation of variables listed in table 1.

Mean and standard deviation of snowfall amount, rainfall amount and seasonal snow cover depth at a station for a winter are computed as follows:

$$
\mu_{j}=\frac{\sum_{j=1}^{n} y_{j}}{n_{j}}, \quad \text { where } y_{j}>0
$$

where $\mu_{j}=$ mean snowfall (rainfall) amount for 9-hr or 15-hr interval, mean snowfall amount for 24-hr interval, mean seasonal snow cover depth; $y_{j}=$ snowfall (rainfall) amount for 9-hr or 15-hr interval, snowfall amount for 24 -hr interval, seasonal snow cover depth, $n_{j}=$ number of records with $y_{j}>0$.

A day is defined as a snow day (a rain day) when snowfall (rainfall) was reported over a period of 24 hours and a day is defined as snow cover day when seasonal snow cover is reported at a station location. SFD, RFD and SCD for a winter at a station are computed using the following expression:

$$
\begin{gathered}
N=\sum_{j=1}^{n} m_{j} \\
m_{j}=\left(\begin{array}{cc}
1, & y_{j}>0 \\
0, & y_{j}=0
\end{array}\right)
\end{gathered}
$$

where $y_{j}$ is snowfall (rainfall) amount in 24-hr interval and snow cover depth, $N=$ total number of snow (rain) days and snow cover days; $m_{j}=1(0)$ for snow day (no snow day), rain day (no rain day) and snow cover day (no snow cover day).

Trend in RC provides an insight on whether the rainfall contribution to seasonal total precipitation amount is increasing (decreasing) due to increasing air temperatures (MX, MN) and decreasing seasonal total snowfall amount. Rainfall contribution $\left(R C_{j}\right)$ to seasonal total precipitation for a winter at a station is defined as follows:

$$
R C_{j}=100 \times \frac{R_{j}}{P_{j}}, \quad \text { where } P_{j}>0
$$

where $R C_{j}=$ rainfall contribution in $\%, R_{j}=$ seasonal total rainfall amount (TR), $P_{j}=$ seasonal total precipitation amount (TP).

Linear regression analysis is used to construct the trend in variables listed in table 1 (Pant and Rupa Kumar 1997; Bhutiyani et al. 2007, 2009, Dimri and Das 2011). Linear regression equation of the following form is developed at each station for surface weather variables listed in table 1 to examine linear trend in them.

$$
S_{j}=A_{j}+B_{j} T_{j}
$$


where $S_{j}$ is the anomaly of any surface weather variable, $A_{j}$ and $B_{j}$ are the regression constant and regression coefficient respectively, and $T_{j}$ is the winter season. $B_{j}$ represents slope of regression line, hence sign of $B_{j}$ represents increasing (decreasing) trend in $S_{j}$. Standard two tail T-test is employed to determine statistical significance of regression coefficient $B_{j}$, i.e., statistical significance of increasing (decreasing) trend in any surface weather variable listed in table 1.

\section{Results and discussion}

\subsection{Trends in maximum, minimum and mean air temperatures}

The MX and MN trends for each station falling in the Shamshawari Range, the Pir Panjal Range and the Great Himalayan Range indicate that a majority of the stations ( 8 of the 11 stations) show an increasing trend in these variables (table $3 \mathrm{a}$ ). Statistically significant increasing trend in MX are found for the stations D, E, G (3080 m) and F (2800 $\mathrm{m})$ in the Pir Panjal Range, and for the stations $\mathrm{I}$ and $\mathrm{K}(2440 \mathrm{~m})$ in the Great Himalayan Range (table 3a). However, the trend in MN seen to be statistically significant at station D in the Pir Panjal Range (table 3a). Anomaly trend in MX and $\mathrm{MN}$ at a station D in the Pir Panjal Range of NWH is shown in figure 2, and it is evident from figure 2 that MX is increasing at a faster rate relative to $\mathrm{MN}$ at a station D. The MX and MN show high positive anomalies in the last decade at a station D (figure 2).

Further, one can see that the trend in MX and MN exhibits regional character (table 3a). Rate

Table 3. Trends in temperatures (MX, MN, MNT), TS, TR, TP, RC, FS9-15, RF9-15 at 11 stations over the NWH and trends in temperatures (MX, MN, MNT), NMI rainfall and PWT over the western Himalayas (WH) (see table 1 for details; Stn=station; $D=$ decade; W=winter; (+) increasing trend; (-) decreasing trend; ** trend statistically significant at $1 \%$ significance level ; * trend statistically significant at $5 \%$ significance level).

(a) Observed linear trends in MX, MN, TS, TR, TP RC, FS9-15 and RF9-15 at 11 station locations in recent decades over the NWH.

\begin{tabular}{|c|c|c|c|c|c|c|c|c|c|}
\hline \multirow[b]{2}{*}{$\begin{array}{l}\text { Mountain } \\
\text { range }\end{array}$} & \multirow[b]{2}{*}{ Stn } & \multicolumn{8}{|c|}{ Parameters } \\
\hline & & $\begin{array}{c}\mathrm{MX} / \mathrm{D} \\
\left({ }^{\circ} \mathrm{C}\right)\end{array}$ & $\begin{array}{c}\mathrm{MN} / \mathrm{D} \\
\left({ }^{\circ} \mathrm{C}\right)\end{array}$ & $\begin{array}{l}\text { TS/W } \\
(\mathrm{mm})\end{array}$ & $\begin{array}{l}\mathrm{TR} / \mathrm{W} \\
(\mathrm{mm})\end{array}$ & $\begin{array}{l}\mathrm{TP} / \mathrm{W} \\
(\mathrm{mm})\end{array}$ & $\begin{array}{c}\mathrm{RC} / \mathrm{D} \\
(\%)\end{array}$ & $\begin{array}{c}\mathrm{FS} 9-15 / \mathrm{D} \\
(\mathrm{cm})\end{array}$ & $\begin{array}{l}\text { RF9-15/D } \\
(\mathrm{mm})\end{array}$ \\
\hline \multirow[t]{3}{*}{$\mathrm{S}$ range } & A & -0.1 & -0.1 & -13.2 & +6.0 & -4.5 & +0.05 & -0.2 & -0.1 \\
\hline & B & +0.7 & +0.4 & +8.8 & +4.0 & +14.8 & +0.03 & -0.9 & $+2.6 *$ \\
\hline & $\mathrm{C}$ & +0.2 & +0.02 & -1.8 & +1.6 & +3.0 & +0.02 & -1.2 & +1.3 \\
\hline \multirow[t]{5}{*}{$\mathrm{P}$ range } & $\mathrm{D}$ & $+1.0 * *$ & $+0.4 * *$ & $-8.2 * *$ & -2.6 & -6.4 & +0.01 & -0.5 & +0.1 \\
\hline & $\mathrm{E}$ & $+1.2 * *$ & +0.5 & $-34.2 * *$ & +2.6 & $-32.4 * *$ & $+0.08 *$ & -1.0 & +2.1 \\
\hline & $\mathrm{F}$ & $+0.9 *$ & +0.2 & -9.8 & +0.7 & -6.3 & +0.17 & -0.6 & -0.5 \\
\hline & G & $+0.8 * *$ & -0.2 & +4.6 & +3.2 & +14.4 & +0.32 & -0.6 & 0.03 \\
\hline & $\mathrm{H}$ & +1.0 & +0.5 & +6.56 & -2.4 & +34.63 & -0.06 & +6.4 & +1.0 \\
\hline \multirow[t]{3}{*}{ G range } & $\mathrm{I}$ & $+1.1 * *$ & +0.4 & $-7.9 * *$ & - & $-8.0 * *$ & - & -0.5 & - \\
\hline & $\mathrm{J}$ & -0.1 & +0.04 & -12.0 & +1.7 & +6.3 & +0.45 & $-1.9 * *$ & 0.2 \\
\hline & K & $+2.0 *$ & +1.8 & $-10.1 *$ & +1.0 & -11.2 & +0.02 & $-1.8 * *$ & 0.1 \\
\hline
\end{tabular}

Table 3(b). Long term trends in temperatures, NMI rainfall and PWT over the WH.

\begin{tabular}{|c|c|c|c|c|c|}
\hline Data type & Data period & $\begin{array}{l}\mathrm{MX} / \mathrm{D} \\
\left({ }^{\circ} \mathrm{C}\right)\end{array}$ & $\begin{array}{c}\mathrm{MN} / \mathrm{D} \\
\left({ }^{\circ} \mathrm{C}\right)\end{array}$ & $\begin{array}{l}\mathrm{MNT} / \mathrm{D} \\
\left({ }^{\circ} \mathrm{C}\right)\end{array}$ & $\begin{array}{l}\text { NMI rainfall } \\
(\mathrm{PWT}) / \mathrm{W}\end{array}$ \\
\hline $\begin{array}{l}\text { Winter temperature data } \\
\text { over the western Himalayas } \\
\text { and north mountainous India } \\
\text { (NMI) rainfall data }\end{array}$ & $\begin{array}{l}1979-2009 \\
31 \text { winters }\end{array}$ & $+1.15 * *$ & $+0.41 * *$ & $+0.78 * *$ & -2.9 \\
\hline $\begin{array}{l}\text { NCAR/NCEP winter } \\
\text { temperature }(700 \mathrm{mb}) \text { and } \\
\text { precipitable water content }\end{array}$ & $\begin{array}{l}1979-2009 \\
31 \text { winters }\end{array}$ & & & $+0.35 *$ & -0.82 \\
\hline Temperature data over western Himalayas & $\begin{array}{l}1902-2007 \\
106 \text { winters }\end{array}$ & $+0.15 * *$ & $+0.10 * *$ & $+0.13 * *$ & \\
\hline $\begin{array}{l}\text { North mountainous India }(\mathrm{NMI}) \\
\text { rainfall data }\end{array}$ & $\begin{array}{l}1845-2006 \\
162 \text { winters }\end{array}$ & & & & +0.30 \\
\hline $\begin{array}{l}\text { NCAR/NCEP winter temperature } \\
\text { and precipitable water content data }\end{array}$ & $\begin{array}{l}1950-2009 \\
60 \text { winters }\end{array}$ & & & +0.10 & $-1.5 * *$ \\
\hline
\end{tabular}




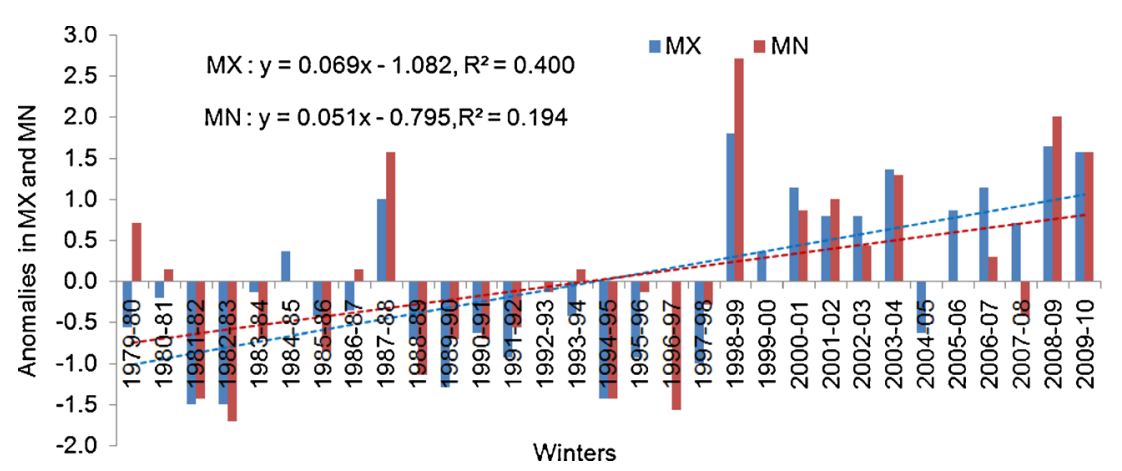

Figure 2. Anomaly trends of temperatures (MX, MN) at a station D in the Pir Panjal Range of the NWH (MX $=$ maximum temperature, $\mathrm{MN}=$ minimum temperature).

Table 4. Trends in snowfall amount of 24-hr interval, seasonal snow cover depth, snow days, rain days, total precipitation days and snow cover days (FS-24=snowfall amount of 24-hr interval; $M S S C D=$ seasonal snow cover depth; SFD=snow days; $R F D=$ rain days; TPD=total precipitation days; $S C D=$ snow cover days; $D=$ decade; $W=$ winter; (+) increasing trend; (-) decreasing trend; **trend statistically significant at $1 \%$ significance level; * statistically significant at $5 \%$ significance level).

\begin{tabular}{|c|c|c|c|c|c|c|c|}
\hline \multirow[b]{2}{*}{$\begin{array}{l}\text { Mountain } \\
\text { range }\end{array}$} & \multirow[b]{2}{*}{ Stn } & \multicolumn{6}{|c|}{ Parameters } \\
\hline & & $\begin{array}{l}\mathrm{FS}-24 / \mathrm{D} \\
(\mathrm{cm})\end{array}$ & $\begin{array}{c}\text { MSSCD/D } \\
(\mathrm{cm})\end{array}$ & $\begin{array}{c}\text { SFD/W } \\
\text { (days) }\end{array}$ & $\begin{array}{c}\text { RFD/W } \\
\text { (days) }\end{array}$ & $\begin{array}{c}\mathrm{TPD} / \mathrm{W} \\
\text { (days) }\end{array}$ & $\begin{array}{c}\mathrm{SCD} / \mathrm{W} \\
\text { (days) }\end{array}$ \\
\hline \multirow[t]{3}{*}{$\mathrm{S}$ range } & $\mathrm{A}$ & +0.04 & -9.2 & -0.5 & $+0.8 *$ & +0.4 & -1.6 \\
\hline & B & -0.6 & +14.9 & $+0.6 *$ & +0.2 & $+1.0 *$ & +0.7 \\
\hline & $\mathrm{C}$ & -1.5 & -0.4 & +0.3 & +0.04 & +0.5 & +0.5 \\
\hline \multirow[t]{5}{*}{$\mathrm{P}$ range } & $\mathrm{D}$ & -0.9 & -2.3 & $-0.4 * *$ & -0.2 & $-0.6 *$ & $-0.9 *$ \\
\hline & $\mathrm{E}$ & -1.6 & $-41.2 *$ & $-1.1 * *$ & +0.2 & $-0.9 *$ & -1.3 \\
\hline & $\mathrm{F}$ & -0.5 & -13.2 & -0.3 & $+0.2 *$ & +0.2 & -0.3 \\
\hline & G & -0.3 & -15.9 & +0.4 & +0.2 & $+0.7 * *$ & -0.01 \\
\hline & $\mathrm{H}$ & +10.1 & -39.1 & $-1.3 *$ & +0.1 & -1.1 & +0.5 \\
\hline \multirow[t]{3}{*}{$\mathrm{G}$ range } & I & -0.8 & -1.4 & -0.3 & - & -0.3 & -0.7 \\
\hline & $\mathrm{J}$ & $-2.4 *$ & -18.4 & +0.02 & $+0.6 * *$ & +0.6 & -0.4 \\
\hline & $\mathrm{K}$ & $-1.9 * *$ & $-20.3 *$ & -0.1 & +0.03 & +0.1 & $-1.3 *$ \\
\hline
\end{tabular}

of increase in MX is found to be higher at high altitude stations compared to low altitude stations consistent with earlier study (Bhutiyani et al. 2007). However, the rate of increase in MX and $\mathrm{MN}$ over different mountain ranges are found to be marginally less compared to the reported average rise in temperatures over the $\mathrm{WH}$ (Bhutiyani et al. 2007; Shekhar et al. 2010). This is likely due to difference in winter data length, frequency of winters and due to temperature averaging of different stations for computing the temperature trend for a mountain range or WH as a whole (Bhutiyani et al. 2007; Shekhar et al. 2010).

\subsection{Trends in snow days, rain days, precipitation days and snow cover days}

Linear trends in SFD, RFD, TPD and SCD are examined to know whether there is any change in them in recent decades over the NWH. SFD show decreasing trend and RFD show increasing trend at most of the stations over the NWH (table 4). Stations with short data length over the NWH tend to show increase in TPD (table 4). However, stations with longer data length (2-3 decades) such as station D, E and I, show statistically significant decrease in TPD during winter season. These findings suggest that SFD have decreased and RFD have increased over the NWH in the last 2-3 decades. TPD have also decreased. Rate of increase in RFD are found higher than the rate of decrease in SFD at a station in the Shamshawari Range of the NWH (figure 3).

Increasing air temperatures (MX, MN, MNT) and decreasing TS may result an early melt of seasonal snow cover, i.e., seasonal snow cover for short period for a winter season. These factors are likely to reduce winter period in terms of availability of seasonal snow cover. Trends in SCD are examined to know whether seasonal snow cover days (duration) show any change over the NWH in recent decades. Most of the stations ( 8 out of the 11 stations) show decline in SCD over the NWH (table 4). This suggests that winter period has reduced in terms of availability of seasonal snow cover. Most of the winters in the last decade are seen to show negative anomaly in SCD at a station $\mathrm{E}$ in the NWH (figure 4). 


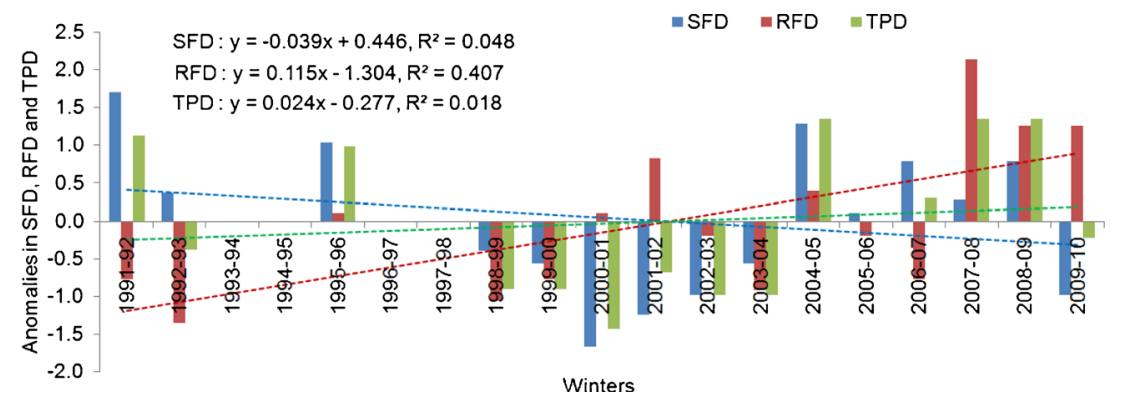

Figure 3. Anomaly trends of snow days, rain days and precipitation days at a station A in the Shamshawari Range of the $\mathrm{NWH}(\mathrm{SFD}=$ snow days; $\mathrm{RFD}=$ rain days; $\mathrm{TPD}=$ total precipitation days $)$.

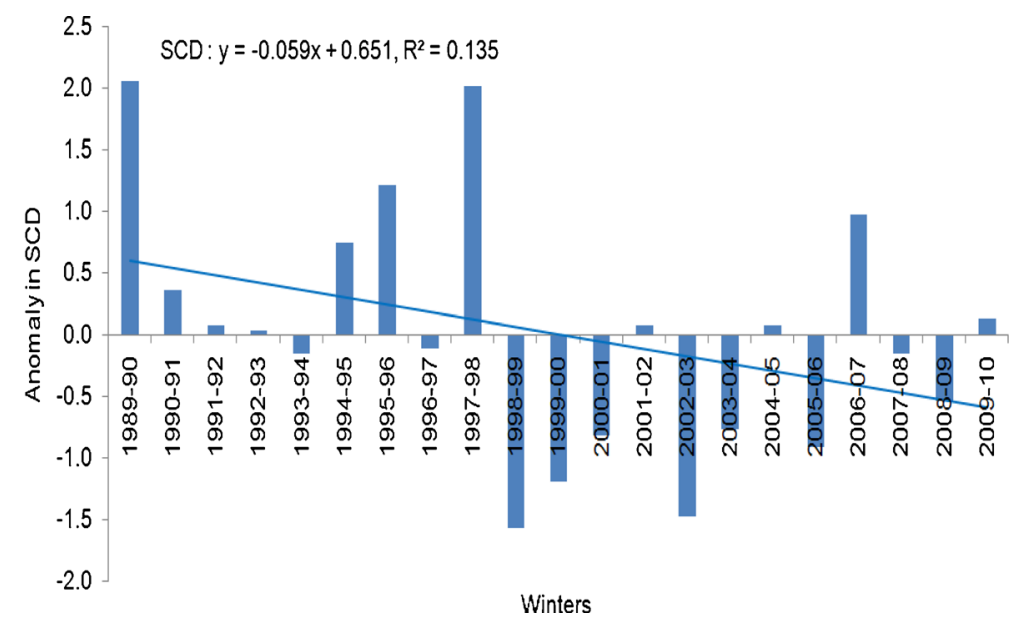

Figure 4. Anomaly trend of snow cover days at a station E in the Pir Panjal Range of the NWH (SCD = snow cover days).

\subsection{Trends in seasonal total snowfall amount, seasonal total rainfall amount, seasonal total precipitation amount and rainfall contribution to seasonal total precipitation amount}

From a global perspective, a few earlier studies reported enhancement and suppression of the precipitation pattern (Fallot et al. 1997; Zhai et al. 1999; Beniston 2003), and in particular for the Himalayas as well (Shrestha et al. 2000; Archer and Fowler 2004; Bhutiyani et al. 2009). These studies did not emphasize the observed trends in TR, RC and TP, and analysis of these variables may provide more insight into the observed trends in various components of winter precipitation (snow, rain and rainfall contribution) and any shift in precipitation type due to increasing air temperatures over the NWH. One can see that most of the stations in the NWH display decreasing trend in TS and TP, while an increasing trend is seen in TR (table 3 ). Stations D and E (the Pir Panjal Range) and stations I and $\mathrm{K}$ (the great Himalayan Range) with longer data length indicate a statistically significant decreasing trend in TS (table 3). TR shows increasing trend at most of the stations. However, TP shows statistically significant decreasing trend at the stations E and I (table 2). Number of stations showing decreasing trend in TP are less compared to the stations showing decreasing trend in TS. This can be attributed to increasing rainfall amount and increasing rainfall contribution to seasonal total precipitation amount during winter season (table 2). Most of the winters show positive anomaly in rainfall and negative anomalies in TS and TP at a station $\mathrm{E}$ in the NWH in the last decade (figure 5). This gives an indication that TS and TP have decreased and TR has increased at a station E in the last decade. Stations D, E, I and $\mathrm{K}$ with longer data length show statistically significant and similar type of trend in TS and TP and, hence, may be reasonably taken as an indicator of observed trends in them over the NWH in recent decades.

\subsection{Trends in snowfall and rainfall amounts of short-time period}

Trends in TS, TR and TP do not provide information on whether snowfall and rainfall amounts of short time intervals are increasing (decreasing). Trends in FS9-15, RF9-15 and FS-24 are examined 


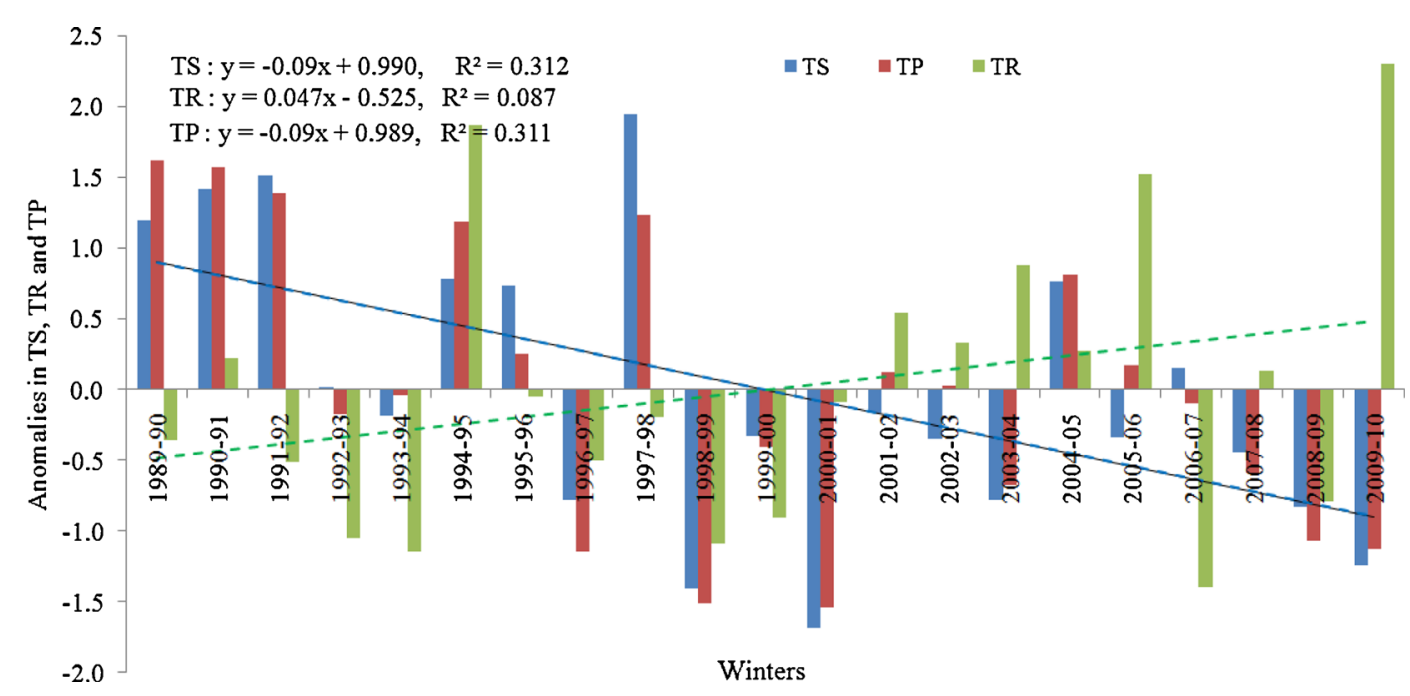

Figure 5. Anomaly trends of seasonal total snowfall amount, seasonal total rainfall amount and seasonal total precipitation amount at a station E in the Pir Panjal Range of the NWH (TS = seasonal total snowfall amount; TR = seasonal total rainfall amount; $\mathrm{TP}=$ seasonal total precipitation amount).

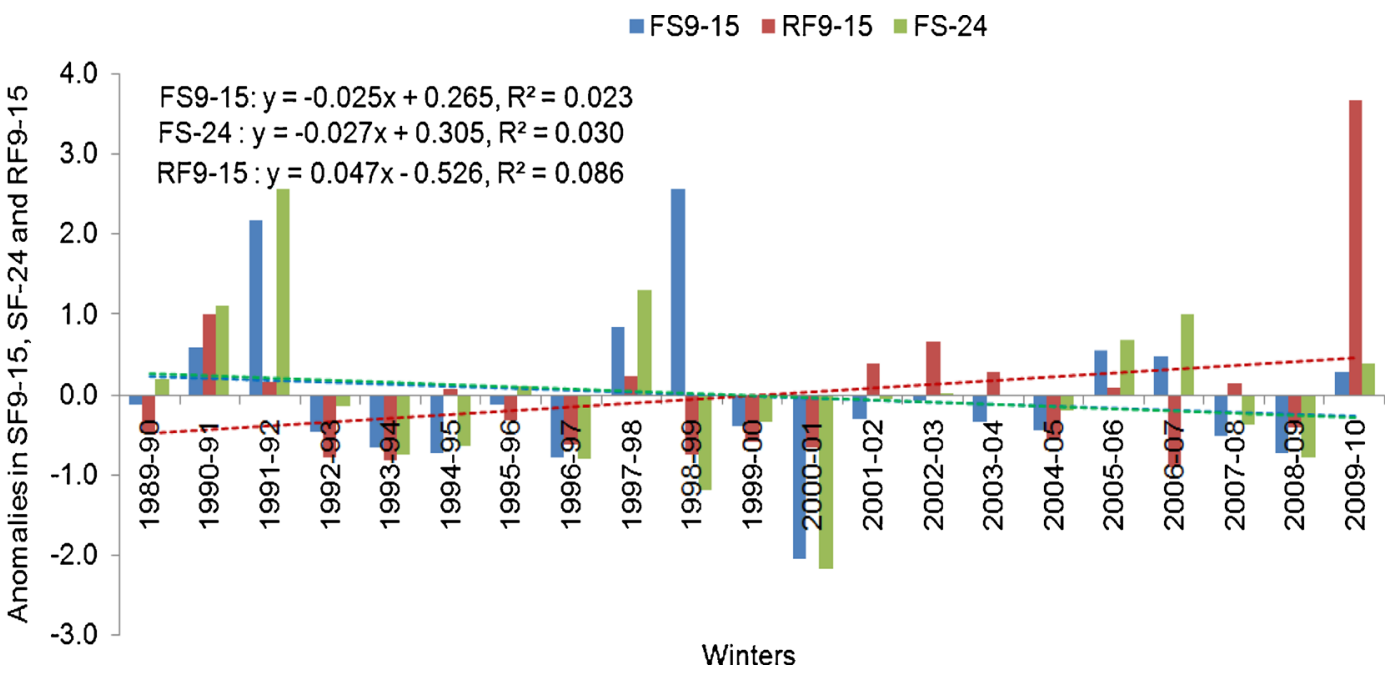

Figure 6. Anomaly trends of snowfall and rainfall amount of short time intervals at a station E in the Pir Panjal Range of the NWH (FS9-15= snowfall in 9-hr or 15-hr interval; FS-24= snowfall in 24-hr interval; RF9-15 = rainfall in 9-hr or 15-hr interval).

to know whether snowfall and rainfall amounts of short time interval are increasing (decreasing) over the NWH. Most of the stations over the NWH show decreasing trend in FS9-15 and FS-24, and increasing trend in RF9-15 (tables 3 and 4). Stations J and $\mathrm{K}(3250 \mathrm{~m})$ in the Great Himalayan Range show statistically significant decreasing trend in FS9-15 and FS-24 (tables 3 and 4). Rate of decrease in FS9-15 and FS-24 is found to be higher at high altitude stations compared to low altitude stations (tables 3 and 4). This can be attributed to the geographic position of stations, local topography and proximity to the moisture sources, etc. Rate of increase in RF9-15 is found to be higher at low altitude stations compared to high altitude stations (table 3). This is likely due to high air temperatures at low altitude stations compared to high altitude stations and increasing air temperatures over the NWH. Trends in FS9-15, FS-24 and RF9-15 suggest that decreasing trend in TS and increasing trend in TR are associated with changes in snowfall and rainfall amounts of short-time intervals. Anomaly trends in FS9-15, RF9-15 and FS-24 at a station $\mathrm{E}$ in the NWH show that snowfall of short-time intervals tend to show decline whereas as rainfall tends to show an increase (figure 6).

\subsection{Trend in seasonal snow cover depth}

Increasing MX, MN, MNT, TR and decreasing TS are likely to influence seasonal snow cover depth. 
This is because decreasing TS and increasing TR may lead to shallow (thin) snow cover build up and increasing air temperatures are likely to cause faster melting of seasonal snow cover. Trend in MSSCD is examined to know whether MSSCD shows any change in recent decades over the NWH.

Ten stations out of the 11 stations display decreasing trend in MSSCD (table 4). Statistically significant decreasing trend in MSSCD is found for a station $\mathrm{E}$ in the Pir Panjal Range and for a station $\mathrm{K}$ in the Great Himalayan Range (table 4). Negative anomaly in MSSCD is found for most of the winters at a station $\mathrm{E}$ in the last decade and anomaly in MSSCD is found consistent with the anomaly in TS (figures 5 and 7).

\section{Similarity of observed trends in different surface weather variables over the NWH}

Trends in surface weather variables listed in table 1 seem to show regional character over the NWH (tables 3 and 4). It is difficult to state clearly that the observed trends in variables listed in table 1 tend to show regional character or it is due to varying data length at different station locations or it is due to combined effect of both of them. This needs to be investigated in future with long homogeneous data series at different station locations. However, broad overview of observed trend

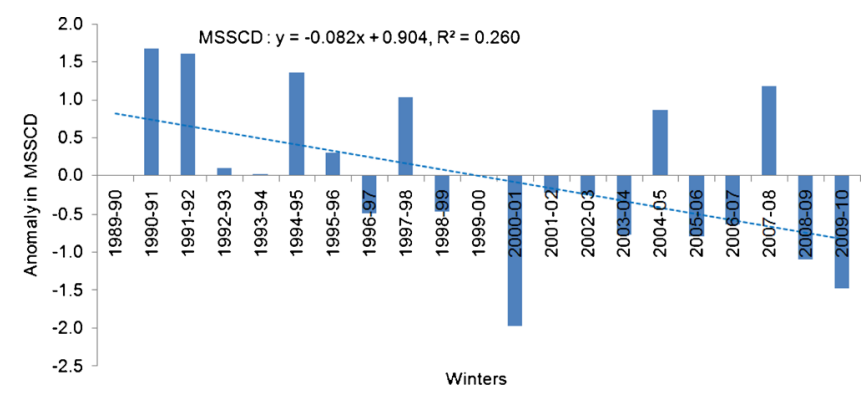

Figure 7. Anomaly trend of seasonal snow cover depth at a station E in the Pir Panjal Range of the NWH. in each variable over the NWH is presented as similarity of type of observed trend at different station locations. Increasing trends in temperatures (MX, MN), RF9-15 and TR is found about $82.0 \%$ (9 out of 11 stations), $80.0 \%$ (8 out of 10 stations) and $80.0 \%$ stations respectively located in different mountain ranges over the NWH (figure 8). Decreasing trends in SF9-15, SF-24, TS, TP and MSSCD is found for $90.9 \%, 81.8 \%, 72.7 \%, 63.6 \%$ and $90.9 \%$ stations respectively (figure 8 ). $90.0 \%$ stations show increasing trend in RFD and $63.6 \%$ stations show decreasing trend in TPD (figure 9). $63.6 \%$ and $72.7 \%$ stations show decreasing trend in SFD and SCD (figure 9). Stations with longer data series (2-3 decades) show same type of trend and statistically significant increasing (decreasing) trend in various surface weather variables over the NWH (tables 2 and 3) which suggests that surface weather variables over the NWH display significant temporal changes in the last 2-3 decades.

\section{Trends in air temperatures and precipitation amount over the WH}

Trends in temperatures and PWT over the WH and rainfall amount over the NMI region are examined using long data series on temperature, PWT and NMI rainfall data (table $3 \mathrm{~b}$ ). Trends in temperatures over the $\mathrm{WH}$ are examined using data of 106 winters (1902-2007) and 60 winters (19502009) (table 3b). Trends in PWT over the WH are examined using PWT data of 60 winters (19502009 ) and trend in NMI rainfall are examined using NMI rainfall data of 162 winters (1845-2006). This is done to get an idea on long term trends in temperature and precipitation over the $\mathrm{WH}$ and the NMI region, and to know whether regional scale data supports (not supports) observed trends in temperatures and precipitation over $\mathrm{NWH}$ in recent decades.

Temperatures (MX, MN, MNT) show statistically significant increase over the $\mathrm{WH}$ in the last 106 winters (table $3 \mathrm{~b}$ ). Long temperature data

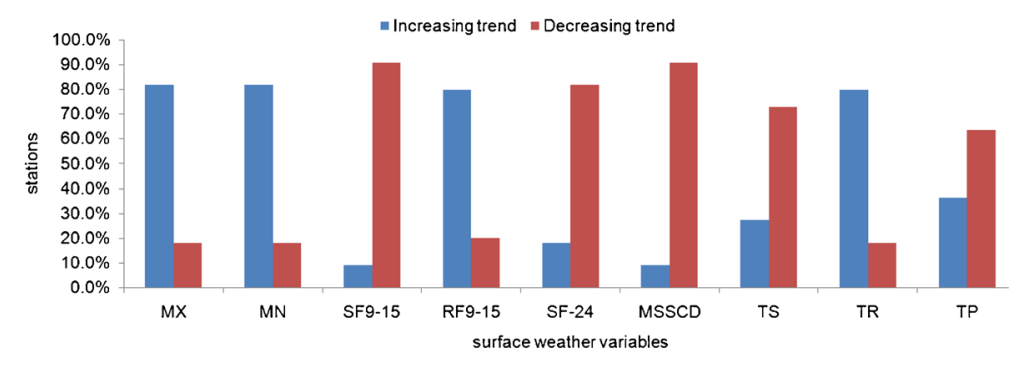

Figure 8. Similarity of observed trend in each variable in different mountain ranges over the NWH $(\mathrm{MX}(\mathrm{MN})=\mathrm{maximum}$ (minimum) temperature; SF9-15 = snowfall amount of 9 or 15 -hr interval; RF9-15 = rainfall amount for 9 or 15 -hr interval; FS-24 = snowfall amount of 24 -hr interval; MSSCD = snow cover depth; TS = seasonal total snowfall amount; TR=seasonal total rainfall amount; $\mathrm{TP}=$ seasonal total precipitation amount). 


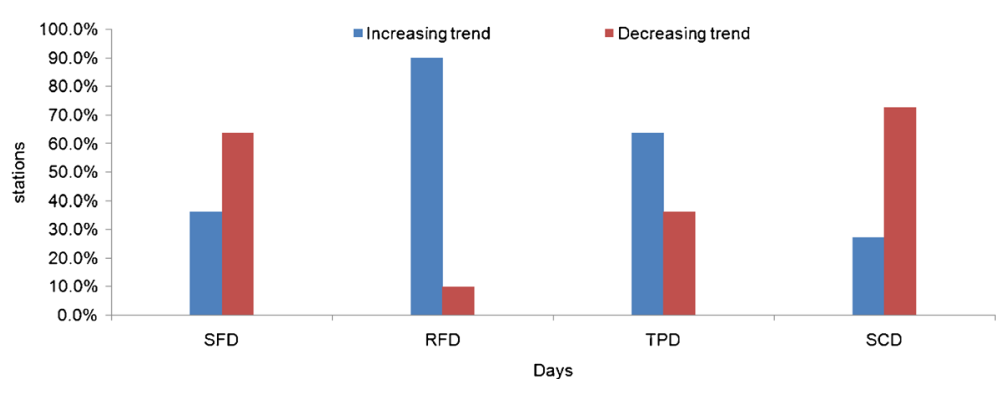

Figure 9. Similarity of observed trend in snow days, rain days, precipitation days and snow cover days in different mountain ranges over the NWH ( $\mathrm{SFD}=$ snow days; RFD = rain days; TPD = total precipitation days; $\mathrm{SCD}=$ snow cover days).

Table 5. Correlation coefficients among anomalies of temperatures ( $M X, M N, M N T)$, anomalies of seasonal total precipitation amount, anomalies of NMI rainfall and anomalies of precipitable water content of NCAR/NCEP reanalysis data $(M X(M N)=$ maximum (minimum) temperature, MNT=mean temperature; TP=seasonal total precipitation amount; WH=western Himalayas; NMI rainfall=north mountainous India rainfall; PWT=precipitable water content of NCAR/NCEP reanalysis data; ** correlation coefficient statistically significant at $1 \%$ significance level; *correlation coefficient statistically significant at $5 \%$ significance level).

\begin{tabular}{|c|c|c|c|c|c|}
\hline \multirow[b]{2}{*}{ Station/area } & \multirow[b]{2}{*}{ Type } & \multicolumn{2}{|c|}{ NCAR/NCEP reanalysis data } & \multicolumn{2}{|c|}{ Western Himalayas } \\
\hline & & $\begin{array}{l}\text { Temperature } \\
(\mathrm{MNT})\end{array}$ & $\begin{array}{c}\text { Precipitable water } \\
\text { content }(\mathrm{PWT})\end{array}$ & Temperature & $\begin{array}{l}\text { NMI } \\
\text { rainfall }\end{array}$ \\
\hline \multirow[t]{4}{*}{$\mathrm{D}$} & MX & $0.82^{* *}$ & & $0.49^{*}$ & \\
\hline & $\mathrm{MN}$ & $0.85^{* *}$ & & 0.23 & \\
\hline & MNT & $0.87^{* *}$ & & $0.44^{*}$ & \\
\hline & $\mathrm{TP}$ & & 0.21 & & -0.05 \\
\hline \multirow[t]{4}{*}{$\mathrm{E}$} & MX & $0.88^{* *}$ & & 0.41 & \\
\hline & MN & $0.69^{* *}$ & & 0.15 & \\
\hline & MNT & $0.84^{* *}$ & & 0.40 & \\
\hline & $\mathrm{TP}$ & & 0.39 & & -0.13 \\
\hline \multirow[t]{4}{*}{ I } & MX & $0.42^{* *}$ & & $0.48^{*}$ & \\
\hline & MN & $0.64^{* *}$ & & 0.41 & \\
\hline & MNT & $0.55^{* *}$ & & $0.51^{*}$ & \\
\hline & $\mathrm{TP}$ & & 0.37 & & 0.07 \\
\hline \multirow[t]{4}{*}{ WH } & MX & 0.11 & & & \\
\hline & MN & 0.23 & & & \\
\hline & MNT & 0.22 & & & \\
\hline & TP & & -.09 & & \\
\hline
\end{tabular}

series over the WH supports that the rate of increase in MX is higher than MN as observed in recent decades over the NWH (table $3 a$ and $b$ ). Rate of increase in temperatures over the $\mathrm{WH}$ in the last three decades is found to be higher than the rate of increase in temperatures in the last 106 winters (table $3 \mathrm{~b})$. NCAR/NCEP reanalysis temperature also show increase in temperatures over the $\mathrm{WH}$ in the last six decades (table $3 \mathrm{~b}$ ). The NMI rainfall data show statistically insignificant increasing trend in rainfall in the last 162 winters (table 3b). However, PWT shows statistically significant decrease in the last six decades over the WH (table 3b).

Correlation coefficients among anomalies of temperatures, TP, NMI rainfall and PWT are computed (table 5). Temperatures (MX, MN and $\mathrm{MNT}$ ) at station locations $\mathrm{D}, \mathrm{E}$ and $\mathrm{I}$ show statistically significant positive correlation with the reanalysis temperature of a grid common to station location and temperature over the WH (table 5). $\mathrm{TP}$ at station locations D, E and I show positive correlation with the PWT of a grid common to station location and insignificant negative correlation with the NMI rainfall (table 5). These results give an indication that regional scale temperature and PWT over the WH may be reasonably taken as an indicator of long-term trend in temperatures and TP over the NWH.

Trends in temperatures and PWT over the WH and trends in NMI rainfall are also examined in the last three decades. Temperatures over the WH show statistically significant increase in the last three decades and results are consistent with the observed trend in temperatures over the NWH (table $3 \mathrm{a}$ and $\mathrm{b}$ ). Decline in NMI rainfall and PWT 


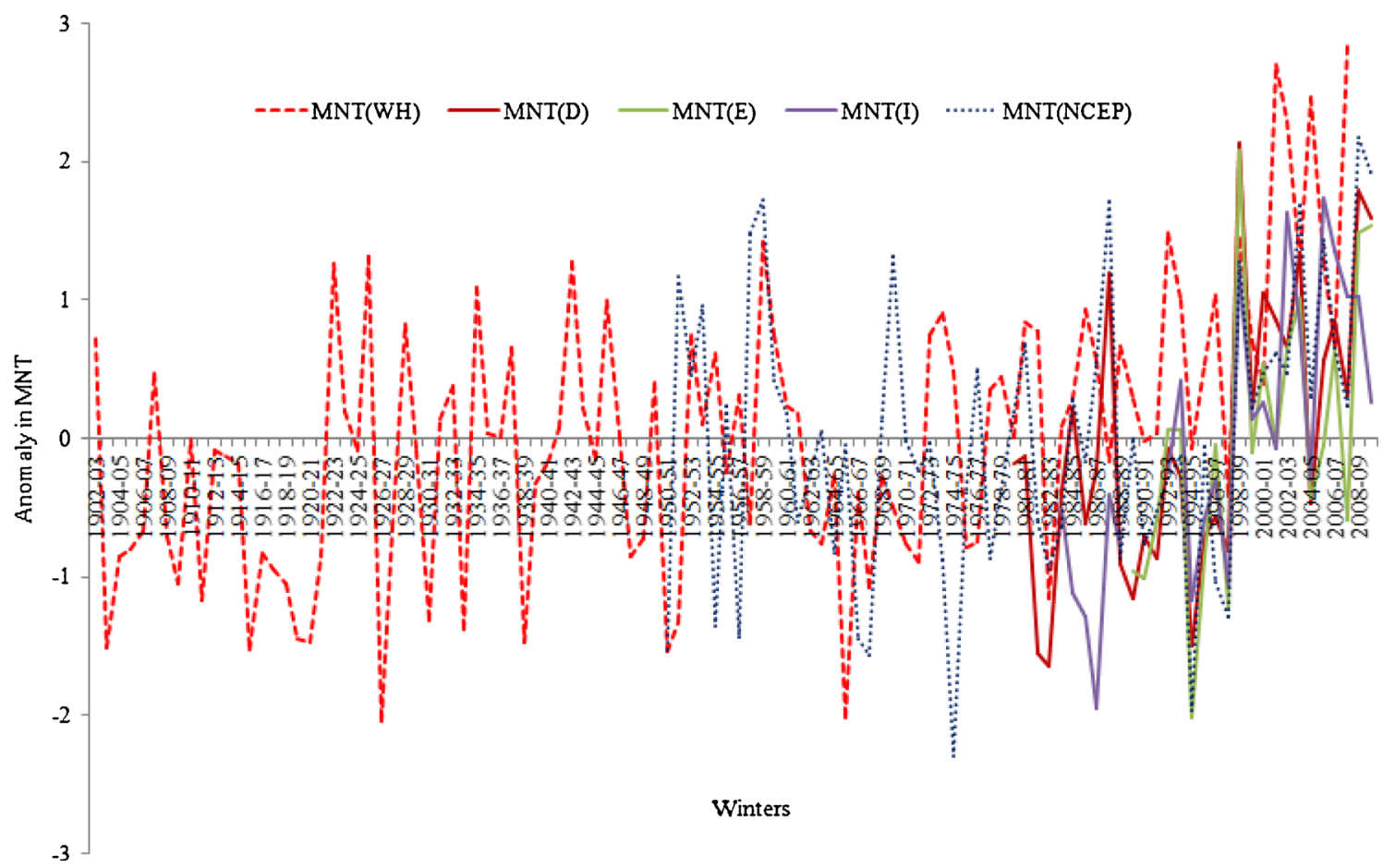

Figure 10. Anomaly of mean air temperature over the western Himalayas $(\mathrm{MNT}(\mathrm{WH})=$ mean air temperature over the (western Himalayas); MNT(D, E, I) = mean air temperature at a station (D, E, I); MNT $(\mathrm{NCEP})=$ mean air temperature over the western Himalayas based on NCAR/NCEP reanalysis data).

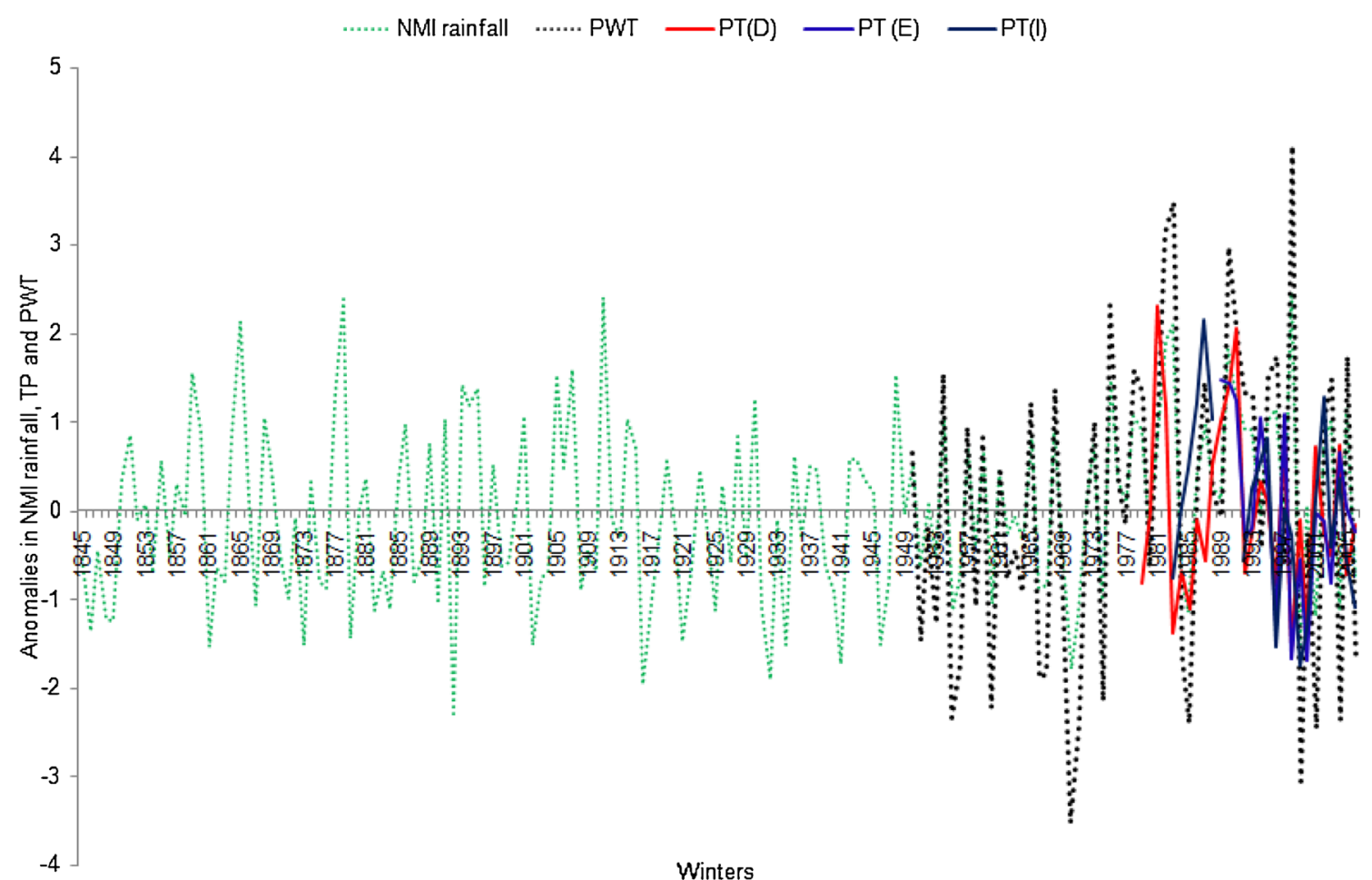

Figure 11. Anomaly of NMI rainfall, seasonal total precipitation amount at stations D, E and I and seasonal total precipitable water content of reanalysis data over the western Himalayas (NMI rainfall = north mountainous India rainfall; $\mathrm{PWT}=$ precipitable water content of $\mathrm{NCAR} / \mathrm{NCEP}$ reanalysis data; $\mathrm{PT}(\mathrm{D}, \mathrm{E}, \mathrm{I})=$ seasonal total precipitation amount at stations D, E, and I. 
over the $\mathrm{WH}$ in the last three decades are also found consistent with the observed trend in TS and TP over the NWH (table $3 \mathrm{a}$ and $\mathrm{b}$ ). These results suggest that observed trends in TS, TP, MX and MN over the NWH in the last three decades are well supported by regional scale temperature, PWT and NMI rainfall. Anomaly of MNT over the $\mathrm{WH}$ region and at station locations D, E and $\mathrm{I}$ in the NWH are shown in figure 10 which suggests that air temperatures show increasing trend in recent decades over the $\mathrm{WH}$, and MNT is found to show continuous consecutive positive anomaly in the last decade at these stations (figure 10). Anomalies of NMI rainfall, PWT and TP at station locations D, E and I are shown in figure 11 which suggest that TP shows decreasing trend over the NWH in the last three decades and decline in TP is also reasonably well supported by NMI rainfall and PWT over the WH.

\section{Conclusion and limitations}

This study is conducted to examine linear trends in various surface weather variables over the Northwest Himalayas. Temperatures (maximum, minimum and mean temperatures), seasonal total rainfall amount, rain days show an increase while seasonal total snowfall amount, seasonal total precipitation amount, snow days and precipitation days show decline over the Northwest Himalayas in recent decades. Seasonal snow cover depth and snow cover days also show a decline. Decrease in snow cover depth and duration have reduced winter period in terms of availability of seasonal snow cover over the Northwest Himalayas in the last three decades.

Long data series of temperature over the Western Himalayas also show an increase in air temperatures and results are consistent with the observed trend in temperatures over the Northwest Himalayas in recent decades. Decline in total precipitation amount over the Northwest Himalayas is reasonably well supported by the NMI rainfall data and precipitable water content of reanalysis data. Same type of trends in various surface weather variables at most of the stations over the Northwest Himalayas suggest that surface weather variables have undergone significant temporal changes in the recent decades.

This study is based on short data length at 11 stations in different mountain ranges over the Northwest Himalayas. Study based on long homogeneous data series over the Northwest Himalayas in future may provide some interesting results. Trends in temperatures, rainfall and precipitable water content over the Western Himalayas and NMI region are examined using coarse resolution data. However, fine resolution data on temperatures and rainfall over the Western Himalayas may provide better insight on temperature and precipitation variability over the Western Himalayas.

\section{Acknowledgements}

Authors are thankful to the anonymous reviewers for positive critical comments on this work which helped to improve the quality of the manuscript. Authors are also thankful to scientists and technical staff of Snow and Avalanche Study Establishment (SASE), India, for collecting data at remote locations under harsh climatic conditions.

\section{References}

Archer D R and Fowler H J 2004 Spatial and temporal variations in precipitation in the Upper Indus Basin, global teleconnections and hydrological implications; Hydrol. Earth. Syst. Sci. 8 47-61.

Beniston M, Diaz F D and Bradley R S 1997 Climatic change at high elevation sites: An overview; Clim. Change $\mathbf{3 6}$ $233-251$.

Beniston M 2003 Climatic change in mountainous regions: A review of possible impacts; Clim. Change 59 5-31.

Bhutiyani M R, Kale V S and Pawar N J 2007 Long-term trends in maximum, minimum and mean annual air temperatures across the northwestern Himalaya during the twentieth century; Clim. Change 85 159-177.

Bhutiyani M R, Kale V S and Pawar N J 2009 Climate change and the precipitation variations in the northwestern Himalaya: 1866-2006; Int. J. Clim. 36 535-548.

Diaz H F and Bradley R S 1997 Temperature variations during the last century at high elevation sites; Clim. Change 36 253-279.

Dimri A P and Das S K 2011 Wintertime climatic trends in the western Himalayas; Clim. Change 111 775-800.

Fallot J M, Barry R G and Hoogstrate D 1997 Variation of mean cold season temperature, precipitation and snow depths during the last 100 years in the former Soviet Union (FSU); Hydrol. Sci. J. 42 301-327.

Fowler H J and Archer D R 2005 Hydro-climatological variability in upper Indus basin and implications for water resources; In: Regional hydrological impacts of climate change - impact assessment and decision making (eds) Wagner $\mathrm{T}$ et al., Proceedings of Symposium S6 held during the Seventh IAHS Scientific Assembly at Foz do lguacu, Brazil, IAHS Publ. 295 131-138.

Kalnay E, Kanamitsu M, Kistler R, Collins W, Deaven D, Gandin L, Iredell M, Saha S, White G, Woollen J, Zhu Y, Chelliah M, Ebisuzaki W, Higgins W, Janowiak J, Mo K C, Ropelewski C, Wang J, Leetmaa A, Reynolds R, Jenne R and Joseph D 1996 The NCEP/NCAR 40-year reanalysis project; Bull. Am. Meteor. Soc. 77 437-471.

Kang S, Xu Y, You Q, Flugel W A, Pepin N and Yao T 2010 Review of climate and cryospheric change in the Tibetan Plateau; Environ. Res. Lett. 5, doi: 10.1088/1748-9326/5/1/015101.

Kothawale D R and Rupa Kumar K 2005 On the recent changes in surface temperature trends over India; Geophys. Res. Lett. 32 L18714.

Kulkarni A V and Bahuguna I M 2002 Glacial retreat in the Baspa Basin, Himalayas, monitored with satellite stereo data; J. Glaciol. 48 171-172. 
Kulkarni A V and Alex S 2003 Estimation of recent glacial variations in Baspa Basin using remote sensing techniques; J. Indian Soc. Rem. Sens. 31 81-90.

Kulkarni A V, Rathore B P, Mahajan S and Mathur P 2005 Alarming retreat of Parbati Glacier Beas basin, Himachal Pradesh; Curr. Sci. 88 1844-1850.

Kulkarni A V, Bahugunna I M, Rathore B P, Singh S K, Randhawa S S, Sood R K and Dhar S 2007 Glacial retreat in Himalaya using Indian remote sensing satellite data; Curr. Sci. 92 69-74.

Li C and Tang M 1986 Changes of air temperature of Qunghai-Xizang plateau and its neighborhood in the past 30 years; Plateau Meteorol. 284 2156-2159.

Pant G B and Borgaonkar H P 1984 Climate of the hill regions of Uttar Pradesh; Him. Res. Develop. 3 13-20.

Pant G B and Rupa Kumar K 1997 Climates of south Asia: Behaviour studies in climatology (John Wiley and Sons: West Sussex, England), pp. 126-127.

Seko K and Takahashi S 1991 Characteristics of winter precipitation and its effects on glaciers in Nepal Himalaya; Bull. Glacier Res. 9 9-16.

Shekhar M S, Chand H, Kumar S, Srinivasan K and Ganju A 2010 Climate change studies in the western Himalaya; Ann. Glaciol. 51 105-112.
Shrestha A B, Wake C P, Mayewski P A and Dibb J E 1999 Maximum temperature trends in the Himalaya and its vicinity: An analysis based on temperature records from Nepal for the period 1971-94; Int. J. Clim. 12 2775-2786.

Shrestha A B, Wake C P, Dibb J E and Mayewski P A 2000 Precipitation fluctuations in the Nepal Himalaya and its vicinity and relationship with some largescale climatological parameters; Int. J. Clim. $20317-$ 327.

Singh P and Arora M 2007 Water resources potential of Himalayas and possible impact of climate change; Jalvigyan Sameeksha 22 109-132.

Sontakke N A, Singh N and Singh H N 2008 Instrumental period rainfall series of the Indian region (18132005): Revised reconstruction, update and analysis; The Holocence 18 1055-1066.

Thompson L G, Yao T, Thompson E M, Davis M E, Handerson K A and Lin P N 2000 A high resolution millennial record of the South Asian monsoon from Himalayan ice cores; Science 289 1916-1919.

Zhai P, Sun A, Ren F, Xiaonin L, Gao B and Zhang Q 1999 Changes in climate extreme in China; Clim. Change 42 203-218. 